\title{
STUDI KASUS PENGARUH STRUKTUR MODAL TERHADAP PROFITABILITAS PERUSAHAAN PO. GAGAK RIMANG PERIODE TAHUN 2000-2007
}

\author{
Mayasari \\ Anceu Yulia
}

\begin{abstract}
Abstrak
PO. Gagak Rimang merupakan perusahaan jasa transportasi atobus yang melayani rute BandungJakarta dan Bandung- Bogor. Ketatnya persaingan di bisnis transportasi menyebabkan PO. Gagak Rimang mengalami tingkat profitabilitas dengan trend yang menurun. Sedangkan di sisi lain, PO. Gagak Rimang harus membiayai aktivitas atau kegiatan bisnisnya (beban operasional). Adanya defisit pembiayaan menyebabkan PO. Gagak Rimang meminjam dana dari pihak bank dengan beban bunga setiap periodenya. Penelitian ini bertujuan untuk mengetahui struktur modal, profitabilitas perusahaan, serta pengaruh struktur modal terhadap profitabilitas perusahaan PO. Gagak Rimang.

Penelitian ini merupakan penelitian deskriptif dan verifikatif dengan metode studi kasus dan explanatory survey. Jangka waktu penelitian berbentuk time series design. Objek penelitian berupa laporan keuangan yang terdiri dari laporan laba rugi dan neraca PO. Gagak Rimang pada periode tahun 1980 sampai dengan periode tahun 2007. Metode penelitian yang digunakan ialah studi kasus dengan teknik purposive sampling. Teknik pengumpulan data dilakukan melalui wawancara dengan pihak perusahaan, pengumpulan dokumen, serta studi literatur.

Hasil penelitian menunjukkan kondisi struktur modal di PO. Gagak Rimang periode tahun 2000 sampai dengan tahun 2003 tergolong baik, dimana jumlah hutang jangka panjang selalu lebih rendah dibandingkan dengan modal sendiri. Sedangkan pada periode tahun 2005 sampai dengan tahun 2007 menunjukkan kecenderungan yang lebih seimbang antara hutang jangka panjang dengan modal sendiri. Tingkat profitabilitas perusahaan dari tahun ke tahun mengalami kecenderungan penurunan. Struktur modal berpengaruh terhadap profitabilitas perusahaan di PO. Gagak Rimang dengan korelasi berkategori sangat kuat dan menghasilkan hubungan tidak searah atau berbanding terbalik antara struktur modal dengan profitabilitas perusahaan, artinya setiap kenaikan jumlah struktur modal akan diikuti oleh penurunan profitabilitas perusahaan, begitupun sebaliknya, setiap kenaikan profitabilitas perusahaan akan diikuti oleh penurunan struktur modal.
\end{abstract}

\section{Kata Kunci: Struktur Modal dan Profitabilitas}

\section{PENDAHULUAN}

Perkembangan dan pertumbuhan ekonomi pada era globalisasi ini, berkembang dengan sangat cepat. Hal itu menuntut bangsa kita untuk terus meningkatkan pembangunan di segala bidang. Perkembangan ekonomi tersebut menuntut kesiapan semua pelaku ekonomi agar selalu dapat beradaptasi dengan perubahan yang mungkin terjadi. Hal ini dikarenakan perkembangan ekonomi menyebabkan persaingan yang tajam diantara badan-badan usaha yang ada. Salah satu bidang yang tumbuh dan berkembang dengan cepat adalah bidang transpotrasi. Hal ini menuntut para pelaku bisnis yang bergerak di bidang jasa transportasi harus menghadapi persaingan antar pengusaha transportasi, baik transportasi laut, udara dan darat. Persaingan di bidang jasa transportasi darat yang melayani jasa angkutan umum terjadi antar perusahaan otobus (PO) yang sejenis maupun dengan perusahaan travel.

Banyaknya perusahaan pesaing yang bergerak di bidang jasa transportasi yang sejenis membuat para penumpang mampunyai banyak pilihan, menurut data yang diperoleh penulis dari dinas perhubungan Kota Bandung terdapat 18 perusahaan yang bergerak pada trayek yang sama yaitu Bandung- Jakarta dan Bandung-Bogor dan juga munculnya jasa travel, yang memungkinkan para penumpang beralih menggunakan jasa travel, saat ini terdapat 10 perusahaan jasa travel yang 


\section{StrategiC}

terdaftar. Belum lagi perusahaan otobus harus bersaing dengan para penyewa kendaraan rumahan yang tidak diketahui berapa banyaknya. Para penumpang merasa lebih nyaman dengan fasilitas yang diberikan oleh jasa travel. Jasa travel siap mengantar para penumpang tanpa harus menunggu di terminal atau halte karena jasa travel siap menjemput di tempat para penumpang dan mengantarkan hingga sampai di tempat tujuan. Menurut Kepala Dinas Perhubungan Kota Bandung Timbul Butar Butar penumpang bus berkurang hingga $12,17 \%$ di tahun 2007. hal ini juga diikuti dengan semakin banyaknya perusahaan travel.

Meningkatnya perusahaan travel dirasakan mengancam kelangsungan usaha perusahaan otobus (PO). Dengan meningkatnya perusahaan travel maka penumpang jasa bus akan beralih menggunakan travel. keadaan ini dapat menurunkan profitabilitas perusahaan otobus $(P O)$. Penurunan profitabilitas perusahaan ini juga terjadi pada PO. Gagak Rimang. Perusahaan ini merupakan salah satu perusahaan yang bergerak di bidang jasa transportasi darat. PO. Gagak Rimang melayani dua trayek pemberangkatan, yaitu trayek Bandung-Jakarta dan Bandung-Bogor. Penurunan tingkat profitabilitas PO. Gagak Rimang yang diukur dengan return on asset (ROA).

Besarnya ROA menunjukkan kemampuan perusahaan mendapatkan laba bersih yang diperoleh dari pemanfaatan aktiva dalam usaha. Tingkat ROA yang tinggi menunjukkan penggunaan aktiva yang dimiliki perusahaan digunakan dengan baik. Namun jika ROA perusahaan rendah hal itu berarti penggunaan aktiva perusahaan yang kurang baik. ROA PO. Gagak Rimang dapat dilihat pada Tabel 1.

Tabel 1

Roa PO. Gagak Rimang Tahun 2000-2007

\begin{tabular}{|c|c|}
\hline Tahun & Return On Asset (ROA) \\
\hline 2000 & $28.49 \%$ \\
\hline 2001 & $30.30 \%$ \\
\hline 2002 & $32.46 \%$ \\
\hline 2003 & $23.73 \%$ \\
\hline 2004 & $21.29 \%$ \\
\hline 2005 & $13.34 \%$ \\
\hline 2006 & $12.85 \%$ \\
\hline 2007 & $11.78 \%$ \\
\hline
\end{tabular}

Sumber: Laporan Laba Rugi PO. Gagak Rimang Tahun 2000-2007.
Berdasarkan Tabel 1 diketahui bahwa tingkat profitabilitas PO. Gagak Rimang mengalami naik turun, penurunan return of asset (ROA) terus dialami perusahaan sejak tahun 2003. Sebelum tahun 2003 perusahaan mengalami kenaikan ROA. Pada tahun 2001 perusahaan mengalami kenaikan ROA sebesar $1,81 \%$, pada tahun 2002 perusahaan kembali mengalami kenaikan ROA sebesar 2,16\%. Tahun 2003 perusahaan mengalami penurunan ROA yang cukup besar yaitu sebesar $8,73 \%$ pada tahun 2004 perusahaan mengalami penurunan ROA sebesar 2,44\%. Kemudian di tahun 2005 mengalami penurunan sebesar $7,95 \%$ dan di tahun berikutnya perusahaan mengalami penurunan ROA sebesar 0,49\%, pada tahun 2007 perusahaan mengalami penurunan ROA sebesar $1,07 \%$. Setelah terjadi penurunan pada tahun 2003, perusahaan merasa kesulitan untuk dapat mempertahankan profitabilitas yang telah dicapai.

Pada tahun 2004 perusahaan mengalami penurunan profitabilitas dikarenakan terjadi penurunan pendapatan dan meningkatnya biayabiaya yang harus dikeluarkan oleh perusahaan. Di tahun ini juga terjadi peningkatan hutang baik hutang dagang maupun hutang bank. Menurut ketua DPP Organda mengatakan bahwa di tahun 2004 perusahaan organda harus mengalami keadaan yang cukup berat karena persaingan yang terjadi dan meningkatnya biaya-biaya yang harus dikeluarkan oleh perusahaan. Peningkatan biaya-biaya yang tidak diikuti dengan peningkatan pendapatan mengakibatkan perusahaan membutuhkan dana dari luar agar kegiatan dalam perusahaan dapat tetap berjalan. Meningkatnya dana yang di dapat dari luar atau dari pinjaman membuat perusahaan harus mengembalikan pinjaman tersebut bersama dengan bunga pinjaman dan hal tersebut dapat menambah biaya yang harus dikeluarkan oleh perusahaan, berkurangnya pendapatan dan meningkatnya dana pinjaman membuat profitabilitas perusahaan mengalami penurunan profitabilitas.

Seharusnya perusahaan dari tahun ke tahun mampu mempertahankan profitabilitas, karena salah satu tujuan dari perusahaan adalah mendapatkan profit yang sebesar-besarnya. Apabila perusahaan telah mampu meningkatkan profitabilitas, maka perusahaan tersebut dapat dikatakan sebagai manajemen yang sukses. Apabila perusahaan terus menerus mengalami penurunan profitabilitas, maka perusahaan harus 
segera bertindak dan mencari penyebab perusahaan mengalami hal tersebut. Apabila keadaan itu dibiarkan terus menerus, maka perusahaan lama kelamaan akan mengalami kesulitan untuk berkembang bahkan dapat mengalami kebangkrutan.

Profit yang ingin dicapai perusahaan bukanlah suatu hal yang mudah, tetapi harus menghadapi berbagai masalah. Banyak faktor yang mempengaruhi naik turunnya tingkat profitabilitas perusahaan baik yang berasal dari faktor eksternal maupun internal. Faktor eksternal perusahaan diantaranya seperti yang telah dijelaskan sebelumnya bahwa. banyaknya perusahaan pesaing yang bergerak di bidang jasa transportasi yang sejenis membuat para penumpang mampunyai banyak pilihan dan juga munculnya jasa travel, yang memungkinkan para penumpang beralih menggunakan jasa travel. Sedangkan faktor internal yang menentukan tingkat profitabilitas perusahaan adalah jumlah hutang dan modal sendiri atau yang disebut juga dengan struktur modal. Salah satu tindakan yang dapat dilakukan perusahaan untuk mencapai profitabilitas yang diharapkan ialah dengan cara menentukan struktur modal yang ideal bagi perusahaan dengan mengurangi pinjaman dan menambah modal perusahaan. Modal perusahaan akan bertambah jika perusahaan mendapatkan profit.

Untuk menunjang pengembangan perusahaan diperlukan modal yang sangat besar seperti untuk pemeliharaan kendaraan dan pemakaian peralatan dan perlengkapan kendaraan yang berkualitas dengan harga yang terjangkau. Peralatan dan perlengkapan yang terus mengalami kenaikan harga membuat perusahaan membutuhkan biaya yang besar untuk dapat membeli barang-barang tersebut. Perusahaan harus bekerja keras untuk dapat memperoleh modal demi kelancaran usahanya, salah satunya modal tersebut diperoleh dari profit tahun sebelumnya yang diperoleh dari hasil penjualan jasa. Modal seringkali dihubungkan dengan kelancaran usaha perusahaan karena itu diperlukan penerapan manajemen yang tepat sehingga perusahaan tidak perlu mengalami kesulitan dalam memperoleh dana yang dibutuhkan. Manajemen suatu perusahaan harus dapat membuat suatu kebijakan yang tepat dalam menentukan kebijakan struktur modalnya agar perusahaan dapat mempertahankan kontinuitas dan dapat mencapai tujuan yang ditetapkan.
Sebaiknya perusahaan tidak hanya mengharapkan profit dari sisi penjualan saja tetapi perusahaan dapat juga menentukan struktur modal yang ideal bagi perusahaan.

Penetapan kebijakan struktur modal biasanya meliputi kebijakan perusahaan dalam menggunakan modal yang dimiliki oleh perusahaan dalam kegiatan usahanya. Perusahaan memiliki modal yang berasal dari pinjaman atau hutang yang diperoleh perusahaan dan modal yang dimiliki perusahaan.

Tingkat profitabilitas suatu perusahaan dipengaruhi oleh berbagai faktor salah satunya disebabkan oleh struktur modal perusahaan. Struktur permodalan yaitu berapa besar aktiva diperoleh dari pinjaman dan berapa besar diperoleh dari pemilik.

Perusahaan memiliki aktiva lancar dan aktiva tetap. Perusahaan juga memiliki modal sendiri dan modal yang berasal dari luar atau pinjaman (hutang) baik hutang dagang maupun hutang yang berasal dari bank. Apabila dalam menjalankan operasional perusahaan jumlah hutang yang dimiliki perusahaan lebih besar dibandingkan dengan jumlah modal sendiri, maka perusahaan akan mengalami kesulitan dalam mengembalikan pinjaman yang disertai dengan bunga atau bunga bank. Diharapkan perusahaan dapat menentukan struktur modal yang ideal sehingga perusahaan dapat menghasilkan profitabilitas yang terus meningkat. penentuan struktur modal yang ideal dapat dilakukan melalui kebijakan dalam menggunakan hutang dan modal dengan sebaikbaiknya untuk dapat mempertahankan profitabilitas yang telah diperoleh. Jika PO. Gagak Rimang tidak dapat meningkatkan atau mempertahankan profitabilitas yang diperoleh perusahaan maka diidentifikasi perusahaan tidak dapat tumbuh dan berkembang bahkan dapat mengancam kelangsungan eksistensi PO. Gagak Rimang di dunia jasa transportasi.

Berdasarkan latar belakang tersebut, PO. Gagak Rimang perlu untuk mempertahankan profitabilitas perusahaan dengan menentukan kebijakan struktur modal perusahaan yang terdiri dari hutang dan modal. Sehingga PO. Gagak Rimang dapat terus menjalankan aktivitas bisnisnya.

Berkaitan dengan hal tersebut, maka penelitian ini dirumuskan dalam tiga masalah pokok yaitu: 


\section{StrategiC}

1. Bagaimana gambaran struktur modal PO. Gagak Rimang.

2. Bagaimana gambaran profitabilitas perusahaan PO. Gagak Rimang.

3. Seberapa besar pengaruh struktur modal terhadap profitabilitas perusahaan PO. Gagak Rimang.

\section{KERANGKA PEMIKIRAN}

Penentuan struktur modal suatu perusahaan sangat penting bagi perusahaan, karena pendanaan aktivitas perusahaan didapat dari struktur modal tersebut. Dana yang diperoleh perusahaan baik yang berasal dari modal sendiri maupun berasal dari pinjaman jangka panjang harus digunakan dengan efektif dan efisien sehingga tujuan dari perusahaan dapat dicapai dengan tepat.

Menurut Bambang Riyanto (2001:22): Struktur finansiil mencerminkan cara bagaimana aktivaaktiva perusahaan dibelanjai, dengan demikian struktur finansiil mencerminkan pula perimbangan, baik dalam artian absolut maupun dalam artian relatif antara keseluruhan modal asing (baik dalam jangka pendek maupun dalam jangka panjang) dengan jumlah modal sendiri.

Berdasarkan pengertian tersebut dapat diketahui bahwa struktur modal merupakan perimbangan atau perbandingan antara modal asing atau modal yang berasal dari pinjaman yang berbetuk hutang, baik hutang jangka panjang maupun hutang jangka pendek dan jumlah modal sendiri. Modal sendiri atau modal yang berasal dari dalam perusahaan tersebut diperoleh dari modal perusahaan, cadangan yang disediakan perusahaan dan profit yang diperoleh perusahaan. Perbandingan antara modal pinjaman dengan modal sendiri dalam suatu perusahaan akan menentukan struktur keuangan dari perusahaan tersebut. Dimana struktur keuangan perusahaan mencerminkan perimbangan antara modal sendiri dan modal pinjaman. Jadi struktur modal suatu perusahaan adalah bagian dari struktur keuangan yang merupakan imbangan antara modal asing atau hutang dengan modal sendiri.

Dalam usaha untuk mendapatkan sumber dana untuk membiayai aktivitas usahanya, perusahaan harus mempertimbangkan pula apa yang disebut bunga pinjaman (utang jangka panjang) yang merupakan beban tetap bagi perusahaan, sebagai diikutsertakannya modal asing didalam struktur modal perusahaan. Dalam hal ini rasio yang akan digunakan adalah long term debt to equity ratio. long term debt to equity ratio merupakan imbangan antara hutang jangka panjang yang dimiliki perusahaan dengan modal sendiri. Dari penghitungan rasio ini, perusahaan dapat mengetahui tingkat profitabilitas perusahaan.

Penentuan kebijakan struktur modal yang ideal bagi perusahaan memiliki salah satu tujuan yaitu memperoleh profitabilitas yang maksimal. Apabila profitabilitas diperoleh, ini menunjukkan indikasi kesuksesan perusahaan dari suatu badan usaha serta merupakan salah satu tujuan yang mendorong perusahaan untuk tetap bertahan dan berkembang. Suatu perusahaan tidak akan mampu untuk bertahan dalam jangka waktu panjang dan mencapai tujuan lain sebagaimana telah direncanakan apabila perusahaan tidak mampu untuk mempertahankan profitabilitas. Menurut $S$. Munawir (2004:33), profitabilitas menunjukkan kemampuan perusahaan untuk menghasilkan laba selama periode tertentu."

Dari pendapat di atas dapat diketahui bahwa profitabilitas perusahaan merupakan kemampuan perusahaan dalam memeperoleh profit selama periode tertentu. Profitabilitas perusahaan diukur dengan kesuksesan perusahaan dan kemampuan menggunakan aktivanya secara produktif, dengan demikian profitabilitas perusahaan dapat diketahui dengan membandingkan antara laba yang diperoleh dalam suatu periode dengan jumlah aktiva atau jumlah modal perusahaan.

Menurut Agus Sartono (2001:245), struktur modal optimal adalah kombinasi yang optimal antara hutang jangka panjang dengan modal sendiri sehingga kombinasi tersebut dapat mendatangkan keuntungan.

Kebijakan manajemen suatu perusahaan dalam menetapkan struktur modal yang ideal bagi perusahaannya diharapkan dapat meningkatkan keuntungan bagi perusahaan tersebut, hal ini sejalan dengan pendapat yang dikemukakan di atas. Perimbangan atau kombinasi antara hutang jangka panjang dengan modal sendiri dalam sebuah perusahaan diharapkan dapat meningkatkan profitabilitas perusahaan tersebut. Jika perusahaan dapat terus meningkatkan profitabilitasnya maka perusahaan akan mengalami kemajuan dan mudah untuk berkembang. Sebaliknya apabila perusahaan tidak dapat meningkatkan atau memeprtahankan 
profitabilitasnya maka perusahaan tersebut akan mengalami kesulitan dalam mengembangkan usahanya bahkan jika keadaan tersebut terus terjadi dikhawatirkan perusahaan akan mengalami kemunduran bahkan mengalami kebangkrutan.

Berdasarkan kerangka teoritis tersebut, dapat dibuat kerangka pemikiran yang menghubungkan antara struktur modal pengaruhnya terhadap profitabilitas perusahaan.

\section{METODE PENELITIAN}

Atas pertimbangan tujuan penelitian, maka penelitian ini bersifat deskriptif dan verifikatif. Penelitian deskriptif adalah penelitian yang bertujuan untuk memperoleh deskripsi mengenai modal kerja dan profitabilitas. Sementara penelitian verifikatif bertujuan untuk menguji kebenaran dari suatu hipotesis yang dilaksanakan melalui pengumpulan data di lapangan, dimana dalam penelitian ini akan diuji apakah modal kerja berpengaruh terhadap profitabilitas.

Mengingat sifat penelitian ini adalah deskriptif dan verifikatif yang dilaksanakan melalui pengumpulan data di lapangan, maka metode penelitian yang digunakan adalah metode studi kasus dan explanatory survey. Oleh karena penelitian dilakukan dalam kurun waktu kurang dari satu tahun, maka metode yang digunakan adalah time series method.

Tabel 2 di bawah ini menyajikan operasionalisasi variabel penelitian.

\section{Tabel 2}

Operasionalisasi Variabel

\begin{tabular}{|c|c|c|c|}
\hline Variabel & Konsep Variabel & Indikator & Skala \\
\hline $\begin{array}{l}\text { Struktur } \\
\text { Modal } \\
\text { (Variabel X) }\end{array}$ & $\begin{array}{l}\text { Struktur modal } \\
\text { ialah } \\
\text { pembelanjaan } \\
\text { permanen di } \\
\text { mana } \\
\text { mencerminkan } \\
\text { perimbangan } \\
\text { antara utang } \\
\text { jangka panjang } \\
\text { dengan modal } \\
\text { sendiri. } \\
\text { (Bambang, } \\
\text { 2001:22) }\end{array}$ & 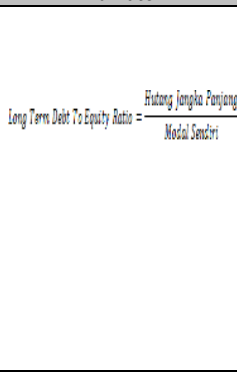 & Rasio \\
\hline $\begin{array}{l}\text { Profitabilitas } \\
\text { (Variabel Y) }\end{array}$ & $\begin{array}{l}\text { Profitabilitas } \\
\text { adalah } \\
\text { kemampuan } \\
\text { perusahaan } \\
\text { untuk } \\
\text { menghasilkan } \\
\text { laba selama } \\
\text { periode tertentu. } \\
\text { (Bambang, } \\
\text { 2001:35) }\end{array}$ & $R O A=\frac{\text { Labar Eersih }}{\text { Total Ahtiva }}$ & Rasio \\
\hline
\end{tabular}

Sumber: Berdasarkan Pengolahan Data

\section{Deskripsi Variabel Penelitian}

\section{Struktur Modal}

Berkembangnya kegiatan usaha perusahaan, memungkinkan perusahaan memperoleh pendapatan yang lebih besar dari sebelumnya. Dengan demikian perlu keseimbangan antara pemenuhan modal dengan menggunakan hutang jangka panjang atau dengan modal sendiri. Modal yang diperoleh perusahaan baik dari pinjaman maupun modal sendiri harus dikelola dengan efektif, sehingga menghasilkan laba yang maksimal.

Berdasarkan hasil penelitian yang diperoleh perubahan struktur modal yang terjadi pada PO. Gagak Rimang dari tahun ke tahun disebabkan adanya penambahan atau pengurangan terhadap perkiraan-perkiraan hutang jangka panjang dan modal milik perusahaan itu sendiri. Pada Tabel 3 dapat dilihat struktur modal PO. Gagak Rimang.

Tabel 3

Struktur Modal PO. Gagak Rimang

\begin{tabular}{|c|r|r|c|}
\hline Thn. & $\begin{array}{c}\text { Hutang Jangka } \\
\text { Panjang (Rp.) }\end{array}$ & $\begin{array}{c}\text { Modal Sendiri } \\
\text { (Rp.) }\end{array}$ & $\begin{array}{c}\text { Struktur } \\
\text { Modal }\end{array}$ \\
\hline 2000 & 200.000 .000 & 2.583 .181 .450 & $7,74 \%$ \\
\hline 2001 & 150.000 .000 & 2.963 .365 .050 & $5,06 \%$ \\
\hline 2002 & 100.000 .000 & 3.536 .946 .100 & $2,83 \%$ \\
\hline 2003 & 300.000 .000 & 2.253 .777 .800 & $13,31 \%$ \\
\hline 2004 & 350.000 .000 & 1.965 .623 .850 & $17,81 \%$ \\
\hline 2005 & 2.000 .000 .000 & 1.862 .877 .950 & $107,36 \%$ \\
\hline 2006 & 1.300 .000 .000 & 1.669 .558 .200 & $77,86 \%$ \\
\hline 2007 & 1.670 .000 .000 & 1.770 .687 .550 & $94,31 \%$ \\
\hline
\end{tabular}

Sumber: Neraca PO. Gagak Rimang diolah kembali

Tabel 3 menunjukkan bahwa jumlah hutang jangka panjang yang tertinggi ada pada tahun 2005 yaitu sebesar Rp. 2.000.000.000,00 dan jumlah hutang jangka panjang terendah ada pada tahun 2002 yaitu sebesar Rp. 100.000.000,00. Jumlah modal sendiri terbesar ada pada tahun 2002 dan modal sendiri terendah ada pada tahun 2006 yaitu sebesar Rp. 1.669.558.200,00. Jumlah struktur modal tertinggi ada pada tahun 2005 yaitu sebesar $107,36 \%$ dan struktur modal terendah ada pada tahun 2002 yaitu sebesar 2,83\%.

Tabel 4 menyajikan data perubahan struktur modal PO. Gagak Rimang dari tahun 2000 sampai dengan 2007.

Dari Tabel 4 dapat dilihat perubahan struktur modal yang terjadi pada PO. Gagak Rimang. Tahun 2001 turun sebesar 2,68\%. tahun 2002 turun sebesar 2,23\%. tahun 2003 naik sebesar $10,48 \%$. tahun 2004 naik sebesar $4,50 \%$. tahun 2005 naik drastis sebesar $89,55 \%$. tahun 2006 


\section{StrategiC}

turun sebesar $29,50 \%$. tahun 2007 naik sebesar $16,45 \%$.

Tabel 4

Perubahan Struktur Modal PO. Gagak Rimang

\begin{tabular}{|c|c|c|}
\hline Thn. & Struktur Modal & Perubahan \\
\hline 2000 & $7,74 \%$ & - \\
\hline 2001 & $5,06 \%$ & $(2,68 \%)$ \\
\hline 2002 & $2,83 \%$ & $(2,23 \%)$ \\
\hline 2003 & $13,31 \%$ & $10,48 \%$ \\
\hline 2004 & $17,81 \%$ & $4,50 \%$ \\
\hline 2005 & $107,36 \%$ & $89,55 \%$ \\
\hline 2006 & $77,86 \%$ & $(29,50 \%)$ \\
\hline 2007 & $94,31 \%$ & $16,45 \%$ \\
\hline
\end{tabular}

Sumber: Neraca PO. Gagak Rimang

Perubahan struktur modal terjadi karena berkurangnya modal sendiri dan bertambahnya modal asing atau modal pinjaman. Penambahan modal asing disini adalah penambahan modal yang berasal dari pinjaman pihak bank, penambahan modal perusahaan dari bank harus dikembalikan beserta bunga yang telah ditentukan setiap periodenya.

Perubahan jumlah struktur modal pada PO. Gagak Rimang pada umumnya disebabkan oleh penambahan jumlah hutang jangka panjang dan berkurangnya jumlah hutang jangka panjang atau jumlah pinjaman yang berasal dari lembaga keuangan.

Jumlah hutang jangka panjang PO. Gagak Rimang dari tahun ke tahun selalu mengalami perubahan. Berikut ini perkembangan hutang jangka panjang PO. Gagak Rimang dapat dilihat pada Tabel 5 di bawah ini.

Tabel 5

Perkembangan Hutang Jangka Panjang PO. Gagak Rimang Tahun $2000-2007$

\begin{tabular}{|r|r|r|r|}
\hline \multirow{2}{*}{ Thn. } & Hutang Jangka & \multicolumn{2}{|c|}{ Perubahan } \\
\cline { 3 - 4 } & Panjang (Rp.) & \multicolumn{1}{|c|}{ (Rp) } & \multicolumn{1}{c|}{$\%$} \\
\hline 2000 & 200.000 .000 & - & - \\
\hline 2001 & 150.000 .000 & 50.000 .000 & $(25 \%)$ \\
\hline 2002 & 100.000 .000 & 50.000 .000 & $(33,33 \%)$ \\
\hline 2003 & 300.000 .000 & 200.000 .000 & $200 \%$ \\
\hline 2004 & 350.000 .000 & 50.000 .000 & $16,67 \%$ \\
\hline 2005 & 2.000 .000 .000 & 1.650 .000 .000 & $471,43 \%$ \\
\hline 2006 & 1.300 .000 .000 & 700.000 .000 & $(35 \%)$ \\
\hline 2007 & 1.670 .000 .000 & 370.000 .000 & $28,46 \%$ \\
\hline
\end{tabular}

Sumber: Neraca PO. Gagak Rimang diolah kembali

Berdasarkan Tabel 5 dapat dilihat pada umumnya perubahan hutang jangka panjang PO. Gagak Rimang mengalami kenaikan yang signifikan, tetapi di samping itu terjadi pula penurunan jumlah hutang jangka panjang.
Kenaikan perubahan hutang jangka panjang PO. Gagak Rimang yang tertinggi terjadi pada tahun 2005 yaitu sebesar Rp. 1.650.000.000,00 atau mencapai $471,43 \%$ dan kenaikan perubahan hutang jangka panjang terendah terjadi pada tahun 2004 yaitu sebesar Rp. 50.000.000,00 atau mencapai $16,67 \%$. Sedangkan penurunan perubahan hutang jangka panjang tertinggi terjadi pada tahun 2006 yaitu sebesar $\mathrm{Rp}$. $700.000 .000,00$ atau mencapai $35 \%$ dan penurunan hutang jangka panjang terendah terjadi pada tahun 2001 yaitu sebesar Rp. 50.000.000,00 atau mencapai $25 \%$.

Selain itu perubahan struktur modal pada PO. Gagak Rimang juga disebabkan oleh penambahan jumlah modal asing dan berkurangnya jumlah modal sendiri. Bertambah dan berkurangnya modal sendiri terjadi karena adanya penambahan dari laba yang diperoleh perusahaan yang kemudian diinvestasikan kembali sebagai modal perusahaan. namun jika perusahaan tidak mendapatkan laba atau laba yang diperoleh sedikit dalam periode tersebut maka modal sendiri juga tidak akan bertambah. Berikut ini dapat dilihat perubahan modal yang dimiliki PO. Gagak Rimang pada Tabel 6 di bawah ini.

Tabel 6

Perubahan Modal Sendiri PO. Gagak Rimang Tahun 2000 - 2007

\begin{tabular}{|l|r|r|r|}
\hline \multirow{2}{*}{ Thn. } & \multirow{2}{*}{ Modal Sendiri } & \multicolumn{2}{|c|}{ Perubahan } \\
\cline { 3 - 4 } & & (Rp) & \multicolumn{1}{c|}{$\%$} \\
\hline 2000 & 2.583 .181 .450 & - & - \\
\hline 2001 & 2.963 .365 .050 & 380.183 .600 & $14,72 \%$ \\
\hline 2002 & 3.536 .946 .100 & 573.581 .050 & $19,36 \%$ \\
\hline 2003 & 2.253 .777 .800 & 1.283 .168 .300 & $(36,28 \%)$ \\
\hline 2004 & 1.965 .623 .850 & 288.153 .950 & $(12,79 \%)$ \\
\hline 2005 & 1.862 .877 .950 & 102.745 .900 & $(5,23 \%)$ \\
\hline 2006 & 1.669 .558 .200 & 193.319 .750 & $(10,38 \%)$ \\
\hline 2007 & 1.770 .687 .550 & 101.129 .350 & $6,06 \%$ \\
\hline
\end{tabular}

Sumber: Neraca PO. Gagak Rimang diolah kembali

Dari Tabel 6 dapat dilihat pada umumnya modal yang dimiliki PO. Gagak Rimang cenderung mengalami penurunan. Tahun 2001 naik sebesar Rp. 380.183 .600 atau mencapai $14,72 \%$, tahun 2002 naik sebesar Rp.573.581.050 atau sebesar $19,36 \%$, tahun 2003 turun sangat drastis sebesar Rp.1.283.168.300 atau mencapai $36,28 \%$. tahun 2004 turun sebesar Rp.288.153.950 atau 12,79\%. tahun 2005 turun sebesar Rp. 102.745 .900 atau 5.23\%, tahun 2006 turun sebesar Rp. 193.319 .750 atau 10,38\%, tahun 2007 naik sebesar 
101.129.350 atau 6,06\%. Dapat dilihat dengan grafik 4.5

Setelah diketahui jumlah masing-masing dari hutang jangka panjang, modal sendiri dan struktur modal PO. Gagak Rimang dapat disimpulkan bahwa:

1. Jumlah rata-rata hutang jangka panjang PO. Gagak Rimang mulai dari tahun 2000 sampai dengan tahun 2007 sebesar Rp. 922.202.669,00

2. Jumlah rata-rata modal sendiri PO. Gagak Rimang mulai dari tahun 2000 sampai dengan tahun 2007 sebesar Rp. 2.325.752.244,00

3. jumlah rata-rata struktur modal PO. Gagak Rimang mulai dari tahun 2000 sampai dengan 2007 sebesar $40,79 \%$

4. Kondisi struktur modal PO. Gagak Rimang pada umumnya mengalami perubahan yang fluktuatif. Hal tersebut dapat dibuktikan dengan adanya kenaikan dan penurunan jumlah struktur modal yang disebabkan bertambah dan berkurangnya jumlah dari hutang jangka panjang dan modal sendiri.

\section{Profitabilitas}

Salah satu cara untuk mengetahui bagaiamana efisiensi dan efektivitas perusahaan dalam menjalankan usahanya dapat diukur dengan mengukur profitabilitas.

Pengukuran profitabilitas dalam penelitian ini menggunakan ROA (Return On Asset). ROA merupakan teknik analisis yang lazim digunakan oleh perusahaan untuk mengukur efektivitas dalam menggunakan keseluruhan dana yang ditanamkan dalam aktiva yang bisa digunakan untuk operasi perusahaan dalam menghasilkan keuntungan. ROA dalam penelitian ini diperoleh dengan cara membandingkan laba bersih yang diperoleh perusahaan dengan jumlah total aktiva (Lukman Syamsudin, 2002: 74)

Perubahan ROA (Return On Asset) yang terjadi pada PO. Gagak Rimang dari tahun ke tahun disebabkan oleh adanya peningkatan atau penurunan laba bersih yang diperoleh dan total aktiva yang dimiliki perusahaan.

Berdasarkan Tabel 7 diketahui bahwa Laba bersih tertinggi yang diperoleh perusahaan ada pada tahun 2002 yaitu sebesar Rp. 1.199.601.550,00 dan laba bersih terendah yang diperoleh perusahaan terjadi pada tahun 2006 yaitu sebesar Rp. 439.073.600,00., sedangkan total aktiva yang dimiliki oleh perusahaan tertinggi berada di tahun 2007 yaitu sebesar Rp Rp. 3.986.024.350,00 dan total aktiva terendah yang dimiliki perusahaan ada di tahun 2004 yaitu sebesar Rp. 2.495.727.350,00. Profitabilitas tertinggi ada pada tahun 2002 yaitu sebesar $32,46 \%$ dan profitabilitas terendah ada pada tahun 2007 yaitu sebesar $11,78 \%$.

Tabel 7

Profitabilitas PO. Gagak Rimang

\begin{tabular}{|c|c|c|c|}
\hline Thn. & $\begin{array}{c}\text { Laba Bersih } \\
\text { (Rp.) }\end{array}$ & $\begin{array}{c}\text { Total Aktiva } \\
\text { (Rp.) }\end{array}$ & $\begin{array}{c}\text { Profita- } \\
\text { bilitas }\end{array}$ \\
\hline 2000 & 819.417 .950 & 2.875 .358 .750 & $28,50 \%$ \\
\hline 2001 & 963.763 .500 & 3.180 .452 .450 & $30,30 \%$ \\
\hline 2002 & 1.199 .601 .550 & 3.695 .929 .600 & $32,46 \%$ \\
\hline 2003 & 634.359 .850 & 2.673 .550 .600 & $23,73 \%$ \\
\hline 2004 & 531.264 .000 & 2.495 .727 .350 & $21,29 \%$ \\
\hline 2005 & 531.613 .950 & 3.986 .024 .350 & $13,34 \%$ \\
\hline 2006 & 430.484 .600 & 3.349 .787 .400 & $12,85 \%$ \\
\hline 2007 & 439.073 .600 & 3.726 .808 .800 & $11,78 \%$ \\
\hline
\end{tabular}

Sumber: Neraca PO. Gagak Rimang

Profitabilitas perusahaan dari tahun ke tahun selalu mengalami perubahan hal ini pada umumnya disebabkan oleh penambahan atau pengurangan laba yang diperoleh perusahaan. laba bersih merupakan selisih antara pendapatan dengan biaya-biaya.

Tabel berikut ini menyajikan data laba bersih PO. Gagak Rimang.

Tabel 8

Laba Bersih PO. Gagak Rimang

\begin{tabular}{|c|c|c|r|}
\hline Thn. & $\begin{array}{c}\text { Pendapatan } \\
\text { (Rp.) }\end{array}$ & $\begin{array}{c}\text { Biaya-Biaya } \\
\text { (Rp.) }\end{array}$ & $\begin{array}{c}\text { Laba Bersih } \\
\text { (Rp.) }\end{array}$ \\
\hline 2000 & 1.766 .016 .500 & 620.419 .450 & 819.417 .950 \\
\hline 2001 & 1.884 .908 .400 & 533.103 .400 & 963.763 .500 \\
\hline 2002 & 2.160 .244 .750 & 71.528 .250 & 1.199 .601 .550 \\
\hline 2003 & 1.631 .730 .550 & 750.502 .150 & 634.359 .850 \\
\hline 2004 & 1.525 .087 .800 & 791.139 .200 & 531.264 .000 \\
\hline 2005 & 1.543 .546 .850 & 809.098 .350 & 531.613 .950 \\
\hline 2006 & 1.586 .132 .250 & 996.154 .250 & 430.484 .600 \\
\hline 2007 & 1.495 .881 .500 & 893.633 .500 & 439.073 .600 \\
\hline
\end{tabular}

Sumber: Laporan Laba Rugi PO. Gagak Rimang

Dari Tabel 8 dapat terlihat bahwa laba bersih PO. Gagak Rimang dari tahun 2000 sampai dengan 2007 mengalami naik turun. Laba bersih tertinggi terjadi pada tahun 2002 yaitu sebesar Rp. 1.199.601.550,00 dan laba bersih terendah terjadi pada tahun 2006 yaitu sebesar $\mathrm{Rp}$. $430.484 .600,00$. besarnya laba bersih dipengaruhi oleh besarnya pendapatan yang diperoleh perusahaan dalam periode tertentu. di samping itu juga besarnya laba bersih perusahaan dipengaruhi oleh jumlah biaya yang dikeluarkan oleh perusahaan dalam periode tertentu seperti biaya 
administrasi, biaya gaji, biaya perlengkapan, biaya pemeliharaan dan biaya penyusutan. Untuk lebih jelasnya berikut ini disajikan table perubahan laba bersih PO. Gagak Rimang.

Tabel 9

Perubahan Laba Bersih PO. Gagak Rimang

\begin{tabular}{|c|r|r|r|}
\hline Tahun & \multirow{2}{*}{$\begin{array}{c}\text { Hutang } \\
\text { Jangka }\end{array}$} & \multicolumn{2}{|c|}{ Perubahan } \\
\cline { 3 - 4 } & Panjang (RP) & Rp & \multicolumn{1}{c|}{$\%$} \\
\hline 2000 & 819.417 .950 & - & - \\
\hline 2001 & 963.763 .500 & 144.345 .550 & $17,62 \%$ \\
\hline 2002 & 1.199 .601 .550 & 235.838 .050 & $24,47 \%$ \\
\hline 2003 & 634.359 .850 & $(565.241 .700)$ & $(47,12 \%)$ \\
\hline 2004 & 531.264 .000 & $(103.095 .850)$ & $(16,25 \%)$ \\
\hline 2005 & 531.613 .950 & 349.950 & $0,07 \%$ \\
\hline 2006 & 430.484 .600 & $(101.129 .350)$ & $(19,02 \%)$ \\
\hline 2007 & 439.073 .600 & 8.589 .000 & $2,00 \%$ \\
\hline \multicolumn{2}{|c|}{ Sumber: Neraca P0. Gagak Rimang } \\
\hline
\end{tabular}

Dari hasil perhitungan Tabel 9 menunjukkan bahwa perubahan laba bersih PO. Gagak Rimang selama periode 2000 sampai dengan 2007 mengalami fluktuatif. Peningkatan laba bersih yang paling tinggi terjadi pada tahun 2002 yaitu sebesar Rp. 235.838.050,00 atau mencapai $24,47 \%$. Peningkatan laba bersih paling rendah terjadi pada tahun 2005 yaitu sebesar Rp. 349.950,00 atau mencapai $0,07 \%$. Sedangkan penurunan laba bersih tertinggi terjadi pada tahun 2003 yaitu sebesar Rp. 565.241.700,00 atau mencapai $47,12 \%$ ) dan penurunan laba bersih terendah terjadi pada tahun 2004 yaitu sebesar Rp. 103.095.850,00 atau mencapai $16,25 \%$.

Selain jumlah laba bersih, jumlah aktiva yang digunakan oleh perusahaan dalam satu periode juga mempengaruhi besar kecilnya jumlah profitabilitas perusahaan. Untuk lebih jelasnya berikut ini disajikan tabel 10 yang menyajikan data perubahan aktiva PO. Gagak Rimang.

Tabel 10

Perubahan Aktiva PO. Gagak Rimang

\begin{tabular}{|c|c|r|r|}
\hline \multirow{2}{*}{ Thn. } & Hutang Jangka & \multicolumn{2}{|c|}{ Perubahan } \\
\cline { 3 - 4 } & Panjang (Rp.) & (Rp) & $\%$ \\
\hline 2000 & 2.875 .358 .750 & - & - \\
\hline 2001 & 3.180 .452 .450 & 305.093 .700 & $10,61 \%$ \\
\hline 2002 & 3.695 .929 .600 & 515.477 .150 & $16,21 \%$ \\
\hline 2003 & 2.673 .550 .600 & $(1.022 .379 .000)$ & $(27,66 \%)$ \\
\hline 2004 & 2.495 .727 .350 & $(177.823 .250)$ & $(6,65 \%)$ \\
\hline 2005 & 3.986 .024 .350 & 1.490 .297 .000 & $59,71 \%$ \\
\hline 2006 & 3.349 .787 .400 & $(636.236 .950)$ & $15,96 \%$ \\
\hline 2007 & 3.726 .808 .800 & 377.021 .400 & $11,25 \%$ \\
\hline
\end{tabular}

Sumber: Neraca PO. Gagak Rimang

Dari hasil perhitungan Tabel 10 menunjukkan bahwa jumlah perubahan aktiva PO. Gagak
Rimang selama periode 2000 sampai dengan periode 2007 mengalami fluktuatif. Jumlah penambahan aktiva yang paling besar terjadi pada tahun 2005 yaitu sebesar Rp. 1.490.297.000,00 atau mencapai $59,71 \%$ dan penambahan terendah terjadi pada tahun 2001 yaitu sebesar Rp. 305.093.700,00 atau mencapai 10,61\% Penurunan jumlah aktiva terbesar terjadi pada tahun 2003 yaitu sebesar Rp. Rp. 1.022.379.000,00 atau mencapai $27,66 \%$ dan penurunan terendah terjadi pada tahun 2004 yaitu sebesar Rp. 177.823.250,00 atau mencapai 6,65\%.

Perubahan profitabilitas terjadi karena berkurangnya laba bersih dan bertambahnya total aktiva atau sebaliknya bertambahnya laba bersih dan berkurangnya total aktiva. Berikut ini pada Tabel 11 dapat dilihat perubahan yang terjadi pada profitabilitas pada tiap periodenya.

Tabel 11

Perubahan Profitabilitas PO. Gagak Rimang

\begin{tabular}{|c|c|c|}
\hline Thn. & Profitabilitas & Perubahan \\
\hline 2000 & $28,50 \%$ & \\
\hline 2001 & $30,30 \%$ & $1,8 \%$ \\
\hline 2002 & $32,46 \%$ & $2,16 \%$ \\
\hline 2003 & $23,73 \%$ & $(8,73 \%)$ \\
\hline 2004 & $21,29 \%$ & $(2,44 \%)$ \\
\hline 2005 & $13,34 \%$ & $(7,95 \%)$ \\
\hline 2006 & $12,85 \%$ & $(0,49 \%)$ \\
\hline 2007 & $11,78 \%$ & $(1,07 \%)$ \\
\hline
\end{tabular}

Sumber: Neraca PO. Gagak Rimang diolah kembali

Perubahan profitabilitas PO. Gagak Rimang selama periode 2000 sampai dengan periode 2007 terjadi kenaikan profitabilitas dari tahun 2000 sampai dengan tahun 2002. Di tahun 2001 terjadi kenaikan profitabilitas sebesar $1,8 \%$ dan di tahun 2002 kenaikan sebesar 2,16\%. Dan di tahun 2003 terjadi penurunan profitabilitas yaitu sebesar $8,73 \%$, tahun 2004 terjadi penurunan sebesar $2,44 \%$, tahun 2005 terjadi penurunan sebesar $7,95 \%$, tahun 2006 terjadi penurunan terendah sebesar $0,49 \%$ dan di tahun 2007 penurunan terjadi sebesar $1,07 \%$.

Setelah diketahui jumlah masing-masing dari total aktiva dan laba bersih PO. Gagak Rimang dapat disimpulkan bahwa:

1. Jumlah rata-rata total aktiva PO. Gagak Rimang mulai dari tahun 2000 sampai dengan tahun 2007 berjumlah Rp. 3.247.954.912,50

2. Jumlah rata-rata laba bersih PO. Gagak Rimang mulai dari tahun 2000 sampai dengan tahun 2007 berjumlah Rp 693.697.375,00 


\section{StrategiC}

3. Jumlah rata-rata profitabilitas PO. Gagak Rimang mulai dari tahun 2000 sampai dengan tahun 2007 sebesar $21,78 \%$

4. Kondisi profitabilitas pada PO. Gagak Rimang lima tahun terakhir terus mengalami penurunan. Hal tersebut dapat dibuktikan dengan adanya kenaikan dan penurunan jumlah laba bersih dan total aktiva

\section{HASIL PENGUJIAN HIPOTESIS PENELITIAN}

Setelah dihitung jumlah struktur modal sebagai variabel $X$ dan Profitabilitas sebagai variabel $Y$ untuk setiap periodenya, maka langkah selanjutnya untuk mencari sebarapa besar pengaruh antara struktur modal dan profitabilitas adalah dengan menggunakan analisis spearman rank. Adapun langkah-langkah dalam penelitian ini sebelum menggunakan analisis korelasi spearman rank adalah sebagai berikut:

1. Data diuji normalitas terlebih dahulu yaitu dengan menggunakan uji chi kuadrat. Dari hasil perhitungan diketahui bahwa data variabel $X$ yaitu struktur modal mempunya chi kuadrat hitung sebesar 9,19 dan chi kuadrat tabel sebesar 7,815 hal tersebut menunjukkan chi kuadrat hitung lebih kecil dibandingkan chi kuadrat tabel, yang berarti data struktur modal berdistribusi tidak normal. Dan chi kuadrat variabel $Y$ yaitu profitabilitas mempunyai chi kuadrat hitung sebesar 3,59, yang berarti data profitabilitas juga berdistribusi normal. Untuk lebih jelas dapat dilihat pada lembar lampiran.

2. Dilakukan uji linieritas regresi karena diantara variabel $X$ dan variabel $Y$. Berdasarkan uji statistik, perhitungan distribusi $t$ didapat thitung $=$ $-5,67$ (lampiran) yang artinya bahwa dalam sampel tidak terdapat hubungan linier antara variabel $Y$ (profitabilitas) dengan variabel $X$ (struktur modal) karena $t_{\text {hitung }}>t_{\text {tabel }}(-5,67>$ $2,447)$.

3. Pada diagram pencar, terdapat gambaran secara kasar bahwa pola hubungan variabel $Y$ (profitabilitas) atas variabel $X$ (struktur modal) adalah pola hubungan yang tidak linier, meskipun hubungan kedua variabel tidak linier akan tetapi tetap dilakukan perhitungan regresi untuk mengetahui sejauh mana perubahan variabel $X$ bila variable $Y$ di naik turunkan, begitupun sebaliknya. Dan model regresinya, yaitu: $Y=\beta_{0}+\beta_{1} X+\varepsilon$. Dari sampel model yang dipergunakan adalah: $Y=b_{0}+b_{1} X+e$.
Kovariasi antara $X$ dan $Y$ sifatnya tidak searah, dalam arti bahwa apabila $X$ berubah makin besar maka $Y$ pun berubah makin kecil atau apabila $X$ berubah makin kecil, maka $Y$ pun berubah makin besar. Kovariasi antara kedua variabel itu disebut kovariasi negatif, ini mengisyaratkan hubungan negatif.

\section{Analisis Korelasi}

Hipotesis yang akan di uji dalam penelitian ini adalah pengaruh struktur modal terhadap profitabilitas PO. Gagak Rimang. Untuk membuktikan hipotesis tersebut, analisis data yang digunakan adalah korelasi Spearman Rank:

Tabel 12

Hasil Perhitungan Korelasi Spearman Rank

\begin{tabular}{|c|c|c|c|c|c|c|}
\hline Thn. & $\mathbf{X}$ & $\begin{array}{c}\text { Rank } \\
(\mathbf{X})\end{array}$ & $\mathbf{Y}$ & $\begin{array}{c}\text { Rank } \\
(\mathbf{Y})\end{array}$ & $\mathbf{d}$ & $\mathbf{d}^{\mathbf{2}}$ \\
\hline 2000 & 7,74 & 3 & 28,5 & 6 & -3 & 9 \\
\hline 2001 & 5,06 & 2 & 30,3 & 7 & -5 & 25 \\
\hline 2002 & 2,83 & 1 & 32,46 & 8 & -7 & 49 \\
\hline 2003 & 13,31 & 4 & 23,73 & 5 & -1 & 1 \\
\hline 2004 & 17,81 & 5 & 21,29 & 4 & 1 & 1 \\
\hline 2005 & 107,36 & 8 & 13,34 & 3 & 5 & 25 \\
\hline 2006 & 77,86 & 6 & 12,85 & 2 & 4 & 16 \\
\hline 2007 & 94,31 & 7 & 11,78 & 1 & 6 & 36 \\
\hline Total & 326,28 & & 174,25 & & & 162 \\
\hline
\end{tabular}

Sumber: Hasil Pengolahan Data

$$
\begin{aligned}
\mathrm{r}_{\mathrm{s}} & =1-\frac{6 \sum d^{2}}{n\left(n^{2}-1\right)} \\
& =1-\frac{6(162)}{8(8-1)} \\
& =-0,93
\end{aligned}
$$

Dari perhitungan di atas, maka diperoleh nilai koefisien korelasi ( $r$ ) antara struktur modal dengan profitabilitas yaitu sebesar $-0,93$. angka tersebut mempunyai arti bahwa

a. Terdapat hubungan korelasi kategori sangat tinggi antara struktur modal dengan profitabilitas

b. Tanda negatif menunjukkan adanya hubungan tidak searah atau terbalik antara variabel struktur modal dan profitabilitas artinya bahwa setiap kenaikan struktur modal maka akan diikuti oleh penurunan profitabilitas.

\section{Analisis Regresi}

Analisis digunakan untuk memprediksikan seberapa jauh perubahan variabel $X$ yaitu struktur modal bila variabel $Y$ yaitu profitabilitas dimanipulasi atau dinaik turunkan. 


\section{StrategiC}

Untuk dapat mengetahui seberapa besar kenaikan atau penurunan yang kedua variabel yaitu struktur modal dan profitabilitas, maka digunakan analisis regresi karena variabel yang diteliti hanya menggunakan satu variabel $X$ dan satu variabel $Y$. Berikut dapat dilihat perhitungan secara manual regresi

$$
\begin{aligned}
a & =\frac{\left(\sum Y i\right)\left(\sum X i^{2}\right)-\left(\sum X i\right)\left(\sum X i Y i\right)}{n \sum X i^{2}-\left(\sum X i\right)^{2}} \\
& =\frac{(174,25)(27070,60)-(326,28)(4704,45)}{8(27070,60)-(326,28)^{2}} \\
& =\frac{4717052,05-1534967,95}{216564,80-106458,64} \\
& =\frac{3182084,10}{110106,16} \\
a & =28,90 \\
b & =\frac{n \sum X i \boldsymbol{Y} \boldsymbol{i}-\sum X i \sum \boldsymbol{Y i}}{n \sum X \boldsymbol{i}^{2}-\left(\sum X \boldsymbol{i}\right)^{2}} \\
& =\frac{8(4704,45)-(326,28)(174,25)}{8(27070,60)-(326,28)^{2}} \\
& =\frac{37635,60-56851,03}{216564,80-106458,64} \\
& =-\frac{19215,43}{110106,16} \\
\mathrm{a} & =-0,17
\end{aligned}
$$

Berdasarkan perhitungan di atas maka dapat dibuat persamaan sebagai berikut:

$Y=28,90-0,17$ (struktur modal)

Dari persamaan di atas maka dapat diinterpretasi sebagai berikut:

a. Jika segala sesuatu pada variabel-variabel independen dianggap konstan maka nilai profitabilitas sebesar 28,90 pertahunnya.

b. Jika terdapat perubahan sebesar 1 pada variabel struktur modal maka nilai variabel profitabilitas akan mengalami penurunan sebesar $0,17 \%$ pertahunnya.

\section{Koefisien Determinasi}

Untuk mengetahui besarnya pengaruh variabel $X$ terhadap $Y$, maka digunakan rumus koefisien determinasi sebagai berikut :

$$
\begin{aligned}
\text { KD } & =r^{2} \times 100 \% \\
& =(-0,93)^{2} \times 100 \% \\
& =86,49 \%
\end{aligned}
$$

Koefisien determinasi digunakan untuk mengetahui derajat hubungan antara struktur modal dengan profitabilitas dapat dihitung dengan menggunakan KD. Dari hasil perhitungan di atas dapat diketahui bahwa $86,49 \%$ profitabilitas perusahaan dipengaruhi oleh struktur modal dan $13,51 \%$ dipengaruhi oleh faktor lain seperti kebijakan dan peraturan pemerintah dan besarnya bunga pinjaman dari bank.

\section{PEMBAHASAN}

\section{Pembahasan Struktur Modal}

Struktur modal yang optimal merupakan kondisi kestabilan antara modal pinjaman dengan modal sendiri, dengan kata lain bahwa modal sendiri lebih besar dari modal pinjaman. Hal ini dapat dilihat dari nilai rata-rata struktur modal PO. Gagak Rimang dari tahun 2000 sampai dengan 2007 sebesar 40,79\% yang mengandung arti bahwa $40,79 \%$ dari total modal yang dimiliki PO. Gagak Rimang mengandung unsur modal sendiri sebesar $59,21 \%$ dan $40,79 \%$ modal yang berasal dari pinjaman.

Konsep struktur modal yang digunakan dalam penelitian ini adalah Long Term Debt To Equity Ratio, dimana struktur modal diperoleh dari perbandingan antara hutang jangka panjang dengan modal pemilik. Kondisi struktur modal PO Gagak Riamang selama periode 2000 sampai 2007 mengalami fluktuatif. Struktur modal dari tahun 2000 sampai dengan 2002 mengalami penurunan, tahun 2003 sampai dengan 2005 mengalami peningkatan struktur modal, tahun 2006 mengalami penurunan dan di tahun 2007 struktur modal PO. Gagak Rimang kembali mengalami peningkatan.

Struktur modal terbesar terjadi pada tahun 2005 yaitu sebesar 107,36\% kenaikan ini terjadi karena perusahaan membutuhkan modal yang besar untuk dapat membiayai peremajaan kendaraan. Dan struktur modal terendah terjadi pada tahun 2002 yaitu sebesar 2,83\%. Untuk lebih jelas mengenai kondisi struktur modal PO. Gagak Rimang dapat dilihat pada Tabel 13.

Tabel 13

Kondisi Struktur Modal PO. Gagak Rimang

\begin{tabular}{|c|c|c|}
\hline Tahun & Struktur Modal & Keterangan \\
\hline 2001 & Penurunan & $\begin{array}{c}\text { Hutang jangka panjang - } \\
\text { \& Modal pemilik + }\end{array}$ \\
\hline 2002 & Penurunan & $\begin{array}{c}\text { Hutang jangka panjang - } \\
\text { \& Modal pemilik + }\end{array}$ \\
\hline 2003 & Peningkatan & $\begin{array}{c}\text { Hutang jangka panjang + } \\
\text { \& Modal pemilik - }\end{array}$ \\
\hline 2004 & Peningkatan & $\begin{array}{c}\text { Hutang jangka panjang + } \\
\text { \& Modal pemilik - }\end{array}$ \\
\hline 2005 & Peningkatan & $\begin{array}{c}\text { Hutang jangka panjang + } \\
\text { \& Modal pemilik - }\end{array}$ \\
\hline 2006 & Penurunan & $\begin{array}{c}\text { Hutang jangka panjang - } \\
\text { \& Modal pemilik - }\end{array}$ \\
\hline
\end{tabular}




\begin{tabular}{|c|c|c|}
\hline Tahun & Struktur Modal & Keterangan \\
\hline 2007 & Peningkatan & $\begin{array}{c}\text { Hutang jangka panjang + } \\
\text { \& Modal pemilik + }\end{array}$ \\
\hline
\end{tabular}

Modal internal PO. Gagak Rimang berasal dari laba bersih yang diperoleh oleh perusahaan dalam periode tersebut. Penggunaan modal sendiri relatif lebih aman dibanding modal pinjaman dalam meningkatkan profitabilitas perusahaan.

Struktur modal optimal memiliki nilai persentase idealnya sebesar $100 \%$ atau sesuai dengan teori konservatif vertikal bahwa angka perbandingannya sebesar 1:1. jika kondisi ini tercapai, maka seharusnya perusahaan tersebut tidak boleh menambah pinjaman dalam jumlah besar karena akan mengakibatkan permodalan perusahaan tersebut berstruktur modal pinjaman karena struktur modal pinjaman yang meningkat dengan ditandai oleh tingginya modal pinjaman akan memberikan resiko finansial yang besar bagi perusahaan berupa pembayaran biaya bunga yang besar.

Meningkatnya biaya bunga yang harus dibayar oleh perusahaan akan menyebabkan menurunnya laba bersih yang diperoleh perusahaan. Selain itu meningkatnya struktur modal pinjaman akan mengakibatkan stabilitas finansial dan jaminan kelangsungan hidup perusahaan menjadi terganggu. Akibatnya perusahaan akan mempunyai biaya bunga yang besar dengan tingkat Long Term Debt to Equity yang tinggi dan hal tersebut berpengaruh terhadap kemampuan perusahaan dalam mencapai target laba bersih perusahaan, dengan kata lain tingkat profitabilitas perusahaan akan menurun.

Penggunaan modal pinjaman akan menguntungkan apabila tingkat rate of return tambahan modal asing lebih besar dibandingkan dengan tingkat rate of return dengan modal tambahan sendiri dan rate of return dengan tambahan modal asing harus lebih besar dari tingkat suku bunga karena apabila rate of return lebih kecil dari tingkat suku bunga akan merugikan perusahaan.

\section{Pembahasan Profitabilitas}

Profitabilitas merupakan kemampuan perusahaan dalam menghasilkan keuntungan dari aktiva yang dimiliki. Hal ini berarti bahwa seberapa besar aktiva dapat menghasilkan keuntungan bagi perusahaan tersebut. Semakin besar laba yang diperoleh perusahaan, maka semakin besar profitabilitas perusahaan. Besarnya profitabilitas perusahaan menandakan produktifnya aktiva yang digunakan atau dengan kata lain aktiva digunakan secara efektif dan efisien. Namun sebaliknya, jika laba yang diperoleh kecil, hal ini berarti bahwa aktiva tidak bekerja dengan efektif, maka harus ada yang dilakukan perusahaan agar aktiva yang dimiliki dapat bekerja produktif sehingga dapat menghasilkan laba semaksimal mungkin.

Profitabilitas PO Gagak Riamang selama periode 2000 sampai dengan periode 2007 cenderung mengalami penurunan. Profitabilitas yang paling tinggi terjadi pada tahun 2002 yaitu sebesar $32,46 \%$ dan profitabilitas yang paling rendah terjadi pada tahun 2007 yaitu sebesar $11,78 \%$. Rata-rata profitabilitas di PO. Gagak Rimang mulai dari tahun 2000 sampai dengan 2007 sebesar 21,78\%. Hal ini berarti bahwa kemampuan dari jumlah modal yang diinvestasikan dalam keseluruhan aktiva usaha dalam Rp. 1,00 dapat menghasilkan keuntungan sebesar $21,78 \%$. Untuk lebih jelasnya mengenai kondisi profitabilitas PO. Gagak Rimang dapat dilihat pada tabel 4.12.

Tabel 14

Kondisi Profitabilitas PO. Gagak Rimang

\begin{tabular}{|c|c|c|}
\hline Tahun & Profitabilitas & Keterangan \\
\hline 2001 & Peningkatan & Laba bersih + \& Total aktiva + \\
\hline 2002 & Peningkatan & Laba bersih + \& Total aktiva + \\
\hline 2003 & Penurunan & Laba bersih - \& Total aktiva - \\
\hline 2004 & Penurunan & Laba bersih - Total aktiva - \\
\hline 2005 & Penurunan & Laba bersih + \& Total aktiva + \\
\hline 2006 & Penurunan & Laba bersih - \& Total aktiva + \\
\hline 2007 & Penurunan & Laba bersih + \& Total aktiva + \\
\hline
\end{tabular}

Sumber: Hasil Pengolahan Data

Profitabilitas dinilai sangat penting, karena untuk melangsungkan hidupnya suatu perusahaan, haruslah berada dalam keadaan yang menguntungkan atau profitable. Tanpa adanya keuntungan akan sulit bagi perusahaan untuk menarik modal dari luar. Para direktur, pemilik perusahaan dan yang paling utama pihak manajemen perusahaan akan berusaha meningkatkan keuntungan ini, karena disadari benar pentingnya arti keuntungan bagi masa depan perusahaan.

Perusahaan yang mampu menghasilkan profitabiliats yang besar mempunyai peluang yang cukup besar untuk meningkatkan pertumbuhan modal sendiri, karena laba yang dihasilkan tersebut kemungkinan akan ditanam kembali dalam perusahaan dalam bentuk laba ditahan. profitabilitas yang positif menunjukkan bahwa 
modal yang diinvestasikan dalam keseluruhan aktiva yang dipergunakan untuk operasi perusahaan mampu memberikan laba bagi perusahaan, sebaliknya profitabilitas yang negatif menunjukkan bahwa dari keseluruhan aktiva yang dipergunakan untuk operasi perusahaan tidak mampu memberikan keuntungan bagi perusahaan yang akhirnya perusahaan akan menderita kerugian sehingga pertumbuhan modal sendiri akan menurun.

\section{Pembahasan Pengaruh Struktur Modal terhadap Profitabillitas}

Hasil pengujian secara empiris bahwa struktur modal optimal memiliki hubungan yang negatif dengan profitabilitas. Hal tersebut menunjukkan adanya hubungan tidak searah atau terbalik antara variabel struktur modal dengan profitabilitas, artinya bahwa setiap kenaikan struktur modal suatu perusahaan maka akan diikuti dengan penurunan profitabilitas perusahaan. Dan begitu pula sebaliknya, setiap penurunan struktur modal akan diikuti dengan kenaikan profitabilitas. Nilai koefisien korelasi (r) sebesar 0,93, angka tersebut menunjukkan bahwa terdapat hubungan korelasi kategori sangat kuat.

Terdapat beberapa fenomena yang terjadi di perusahaan yang mengakibatkan kenaikan struktur modal akan tetapi tidak diikuti dengan kenaikan profitabilitas:

1. Banyaknya kendaraan yang tidak beroperasi karena berkurangnya pengguna jasa transportasi bus dan makin banyaknya perusahaan yang bergerak di bidang jasa transportasi untuk trayek Bandung- Jakarta dan Bandung- Bogor seperti perusahaan travel, perusahaan pesawat terbang. Sedangkan biaya operasional untuk kendaraan tetap ada meskipun kendaraan tersebut tidak beroperasi

2. Adanya kendaraan yang kondisinya sudak banyak kerusakan sehingga efektivitas perjalanan kurang lancar. Dan semakin meningkatnya biaya yang harus dikeluarkan untuk pemeliharaan kendaraan tersebut.

3. Penurunan laba bersih perusahaan yang disebabkan oleh penurunan pendapatan dan disertai dengan pengeluaran biaya operasional perusahaan yang terus meningkat

4. Ketika perusahaan akan melakukan peremajaan kendaraan, perusahaan membutuhkan biaya yang cukup besar untuk membiayai kegiatan tersebut maka perusahaan memutuskan untuk menggunakan modal pinjaman.

Fakta tersebut menunjukkan bahwa struktur modal yang kurang produktif dapat menyebabkan perusahaan tidak dapat menghasilkan laba tapi perusahaan akan menderita rugi bunga. Oleh karena itu PO. Gagak Rimang perlu memperhatikan struktur modal karena dengan struktur modal yang tepat maka perusahaan dapat melangsungkan kegiatan operasionalnya tanpa mengalami kesulitan dalam menghadapi ancaman yang mungkin timbul karena adanya krisis keuangan.

Sehingga dari penjelasan di atas dapat disimpulkan bahwa dengan penetapan struktur modal yang tepat maka dapat diperoleh laba bersih yang tinggi dan secara langsung akan berpengaruh pada produktifitas perusahaan.

Sedangkan untuk mengetahui derajat hubungan antara struktur modal dengan produktifitas dapat dihitung dengan menggunakan koefisien detreminasi (KD). Dari hasil perhitungan menunjukkan nilai sebesar $86,49 \%$. Hal ini berarti bahwa $86,49 \%$ profitabilitas perusahaan dipengaruhi oleh struktur modal dan sisanya sebesar $13,51 \%$ dipengaruhi oleh faktor lain seperti kebijakan dan peraturan pemerintah dan besarnya bunga pinjaman dari bank.

\section{SIMPULAN DAN SARAN}

\section{Simpulan}

Berdasarkan hasil penelitian secara deskriptif maupun verivikatif, dapat disimpulkan beberapa hal terkait dengan penelitian ini, yaitu:

1. Kondisi struktur modal di PO. Gagak Rimang periode tahun 2000 sampai dengan tahun 2003 tergolong baik, dimana jumlah hutang jangka panjang selalu lebih rendah dibandingkan dengan modal sendiri. Sedangkan pada periode tahun 2005 sampai dengan tahun 2007, menunjukkan kecenderungan yang lebih seimbang antara hutang jangka panjang dengan modal sendiri.

2. Berdasarkan sisi Profitabilitas. Diketahui bahwa di PO. Gagak Rimang, tingkat profitabilitas perusahaan dari tahun ke tahun mengalami kecenderungan terjadinya penurunan tingkat profitabilitas. 
3. Struktur modal berpengaruh terhadap profitabilitas perusahaan di PO. Gagak Rimang dengan korelasi berkategori sangat kuat dan menghasilkan hubungan tidak searah atau berbanding terbalik antara struktur modal dengan profitabilitas perusahaan, artinya setiap kenaikan jumlah struktur modal akan diikuti oleh penurunan profitabilitas perusahaan, begitupun sebaliknya, setiap kenaikan profitabilitas perusahaan akan diikuti oleh penurunan struktur modal.

\section{Saran}

Adapun rekomendasi yang dikemukakan oleh penulis adalah sebagai berikut:

1. Pihak manajemen PO Gagak Rimang agar lebih selektif dalam menggunakan modal yang akan digunakan untuk kegiatan usaha. Sebaiknya perusahaan lebih memfokuskan pada penggunaan modal sendiri atau dana internal dibandingkan dengan penggunaan modal asing atau pinjaman, karena modal yang berasal dari pinjaman memiliki resiko yang cukup besar bagi perusahaan, selain itu dengan menggunakan modal sendiri maka perusahaan dapat mengurangi biaya bunga yang harus dibayar perusahaan kepada pihak bank.

2. Perusahaan harus dapat meningkatkan pendapatan dengan cara menggunakan aktiva yang dimiliki secara produktif sehingga profitabilitas perusahaan dapat meningkat.

3. Dalam rangka meningkatkan profitabilitas $P O$ Gagak Rimang, sebaiknya perusahaan mengurangi aktiva yang kurang menguntungkan bagi perusahaan. misalnya perusahaan dapat mengurangi kendaraan yang sudah rusak maka secara tidak langsung akan mengurangi biaya pemeliharaan kendaraan dan secara langsung akan menambah laba perusahaan.

\section{DAFTAR PUSTAKA}

Ahmad Riahi Belkaouli. 2000. Accounting Theory. Jakarta: Salemba Empat.

Ashari Darsono. 2005. Pedoman Praktis Memahami Laporan Keuangan. Yogyakarta: Andi.

Bambang Riyanto. 2004. Dasar-dasar Pembelanjaan Perusahaan. Yogyakarta: BPFE.

Buchari Alma. 2001. Pengantar Bisnis. Bandung: Alfabeta.
Hanafi M, Halim A. 2007. Analisis Laporan Keuangan. Yogyakarta: UPP STIM YKPN.

Harnanto. 1997. Analisa Laporan Keuangan. Yogyakarta: AMP YKPN

Hendriksen. Eldons. 1999. Teori Akuntansi. Jakarta: Erlangga.

Husein, Umar. 2003. Metode Riset Bisnis. Jakarta: PT Gramedia Pustaka.

Husnan Suad dan Enny Pudjiastuti. 2004. Dasardasar Manajemen Keuangan. Yogyakarta: UPP AMP YKPN.

J C Van Horne, J M Wachowicz JR. 2005. Fundamentals of Financial Manajemen. Jilid 1 dan 2. Jakarta: Salemba Empat.

James 0 Gill. 2004. Dasar-dasar Analisis Keuangan. Jakarta: PPM.

Mas'ud, Machfoedz. 1984. Akuntansi Manajemen. Yogyakarta: BPFE.

Masri Singarimbun dan Sofian Effendi. 2006. Metode Penelitian Survai. Jakarta: LP3ES.

Miswanto dan Eko Widodo. 1998. Manajemen Keuangan 1. Jakarta: Gunadarma

Mohammad Nasir. 2003. Metode Penelitian. Jakarta: Ghalia Indonesia.

Muhammad Joko Susilo. 2007. Kurikulum Tingkat Satuan Pendidikan. Yogakarta: Pustaka Pelajar.

Needles. et. al. 1986. Prinsip-Prinsip Akuntansi. Diterjemahkan oleh Tasnim Ali Widjanarko. Jakarta: Erlangga.

Nirwana Sk. Sitepu. 1994. Analisis Regresi dan Korelasi. Bandung: Unit Pelayanan Statistika FPMIPA, Universitas Padjajaran.

Paul, A Samuelson, William D Nordhaus. 1997. Mikro Ekonomi Edisi Keempatbelas. Jakarta: Erlangga.

Riduwan. 2005. Metode dan Teknik Menyusun Tesis. Bandung: CV. Alfabeta.

Rosmina Vinoria. 2004. Pengaruh Produktivitas Tenaga Kerja Langsung terhadap Tingkat Profitabilitas Pada PT Multi Instrumentasi Bandung. Bandung: Jurusan Pendidikan Ekonomi dan Koperasi UPI.

S. Munawir. 2004. Analisis Laporan Keuangan. Yogyakarta: Liberty

Sahlan Akdon. 2005. Aplikasi Statistika dan Metode Penelitian untuk Administrasi dan Manajemen. Bandung: Dewa Ruchi.

Sartono, Agus. 2001. Manajemen Keuangan Teori dan Aplikasi. Yogyakarta: BPFE

Soemarso, SR. 2004. Akuntansi Suatu Pengantar. Jakarta: Rineka Cipta

Sopyan Syarif Harahap. 2008. Analisis Kritis atas Laporan Keuangan. Jakarta: PT Raja Grafindo Persada. 
Sudjana. 2000. Teknik Analisa Regresi dan Korelasi. Bandung: Tarsito.

Sugiyono. 2007. Statistika untuk Penelitian. Bandung: CV. Alfabeta.

Sugiyono. 2008. Metode Penelitian Bisnis. Bandung: CV. Alfabeta.

Suharsimi Arikunto. 2006. Prosedur Penelitian Suatu Pendekatan Praktik. Jakarta: Rineka Cipta.

Syntia A. Sari. 2006. Analisis Hubungan Struktur Modal Berdasarkan Statistic Trade Off Theory dan Peckhing Order Theory pada Perusahaan Public di BEJ Periode Tahun 2002-2004. Jakarta: Universitas Bina Nusantara.

Wiwin Awaliyah. 2004. Pengaruh Partisipasi Anggota Dan Struktur Modal Terhadap Efektivitas Koperasi. Bandung: Jurusan Pendidikan Ekonomi UPI. 